\title{
DOMEIN VERKLARING DALAM PENDAYAGUNAAN TANAH DI ACEH
}

\author{
Zainuddin $^{1)}$, Zaki Ulya ${ }^{2)}$ \\ 1), 2) Dosen Fakultas Hukum Universitas Samudra, Meurandeh - Langsa \\ zainuddin.nurbed@gmail.com | zaki.ulya@gmail.com
}

\begin{abstract}
The regulation of domein verklaring (the right to control the state) is regulated in Article 33 Paragraph (3) of the 1945 Constitution which is further regulated in Law No. 5 of 1960 on Agrarian Principles. This law is a legal reform in the field of agrarian. the problem of abandoned land is a widespread problem in Indonesia, including in Aceh. The interesting thing to consider in terms of state control over special land in Aceh is the enactment of three different legal systems in Aceh and the emergence of Aceh and Baitul Mal Land Agency institutions which have the authority to manage and utilize the land rights.

Keywords: Domein Verklaring, Land Utilization, Aceh
\end{abstract}

Abstrak, Pengaturan mengenai domein verklaring (hak menguasai negara) diatur dalam Pasal 33 Ayat (3) UUD Tahun 1945 yang kemudian diatur lebih lanjut dalam UU No. 5 Tahun 1960 tentang Pokok-Pokok Agraria. Undang-undang ini merupakan sebuah reformasi hukum dalam bidang agraria. permasalahan tanah terlantar merupakan permasalahan yang marak terjadi di Indonesia, termasuk di Aceh. Prihal yang menarik dikaji dalam hal hak menguasai negara dibidang pertanahan khusus di Aceh adalah masih berlakunya tiga sistem hukum yang berbeda di Aceh serta munculnya kelembagaan Badan Pertanahan Aceh dan Baitul Mal yang memiliki wewenang untuk mengelola dan mendayagunakan hak atas tanah tersebut.

Kata Kunci: Domein Verklaring, Pendayagunaan Tanah, Aceh

\section{Pendahuluan}

Menelusuri pada catatan sejarah ditemukan sebuah aturan hukum yang telah disahkan pada masa penjajahan Belanda terkait bidang pertanahan. Regulasi yang dimaksud yaitu Agrarische Wet khususnya pasal 51 I.S. ${ }^{1}$ Filosofis dari pemberlakuan Domein Verklaring disatu sisi adalah untuk menjamin pemanfaatan tanah yang baik diduga maupun terbukti pemiliknya tidak dapat membuktikan hak atas tanah yang telah dikelolanya selama bertahun-tahun. Adapun fungsi penting domein verklaring yaitu sebagai landasan pemerintah agar dapat memberikan tanah kepada masyarakat seperti hak egendom, hak erfpacht, dan lainnya. Jika seorang masyarakat mengakui suatu bidang tanah adalah hak miliknya maka perlu dilakukan pembuktian atas tanah yang dimilikinya.

Adapun dasar hukum dalam UUD NRI Tahun 1945, terkait penguasaan negara atas tanah diatur dalam Pasal 33 Ayat (3) UUD NRI Tahun 1945 yang berbunyi bahwa:

${ }^{1}$ Effendi Perangin, 401 Pertanyaan dan Jawaban tentang Hukum Agraria, Cet. I, (Jakarta: Rajawali, 1986), hlm. 161 
"Bumi dan air dan kekayaan alam yang terkandung di dalamnya dikuasai oleh negara dan dipergunakan untuk sebesar-besar kemakmuran rakyat".

Pasca kemerdekaan Indonesia dengan disahkannya UUD NRI Tahun 1945 dan diberlakukannya Undang-Undang No. 5 Tahun 1960 tentang Pokok-Pokok Agraria memberi kemungkinan tercapainya penggunaan yang bermanfaat dari bumi, air dan kekayaan alam yang terkandung di dalamnya bagi kepentingan rakyat dan negara.

Penjabaran lebih jauh dari hak menguasai tanah oleh negara, terdapat pada pasal 2 Undang-undang Nomor 5 Tahun 1960 tentang Peraturan Dasar Pokok-pokok Agraria yang menyatakan bahwa: "bumi, air dan ruang angkasa, termasuk kekayaan alam yang terkandung didalamnya itu pada tingkatan tertinggi dikuasai oleh Negara, sebagai organisasi kekuasaan seluruh rakyat". asas ini sebenarnya memiliki semangat pengganti asas domein verklaring yang berlaku pada masa colonial belanda, yang ternyata hanya memberikan keuntungan pada pemerintahan colonial belanda pada masa itu. ${ }^{2}$

Winahyu Erwiningsih dalam tulisannya menyebutkan bahwa frasa kekuasaan negara atas tanah sangat mudah dilakukan penafsiran yang dapat ditentukan untuk kepentingan penguasa, sementara itu keberlakuan UU No. 5 Tahun 1960 sendiri masih banyak yang harus diatur lebih lanjut aturan pelaksanaannya. ${ }^{3}$ Sementara itu, Budi Harsono memberikan penjelasan mengenai konsep hak menguasai negara yang tertuang dalam Pasal 33 Ayat (3) UUD NRI Tahun 1945 yaitu Bumi, air dan kekayaan alam yang terkandung dalam bumi adalah pokok-pokok kemakmuran rakyat. Sebab itu harus dikuasai oleh negara dan dipergunakan untuk sebesar-besar kemakmuran rakyat. ${ }^{4}$ Domein verklaring merupakan dasar bagi negara dalam memberikan hak atas tanah kepada pihak lain selaku pemilik tanah. ${ }^{5}$

Terkait penafsiran tentang hak menguasai negara telah ditafsirkan oleh Mahkamah Konstitusi dalam beberapa perkara berbeda dan diputuskan dalam Putusan

Apabila ditinjau dari Pasal 2 Ayat (2) Undang-Undang Nomor 5 Tahun 1960, cakupan hak menguasai negara terdiri dari: mengatur dan menyelenggarakan peruntukan, penggunaan, persediaan dan pemeliharaan bumi, air dan ruang angkasa tersebut; menentukan dan mengatur hubungan-hubungan hukum antara orang-orang dengan bumi, air dan ruang angkasa; dan mengatur hubungan-hubungan hukum antara orang-orang dan perbuatan -perbuatan hukum yang mengenai bumi, air dan ruang angkasa. ${ }^{6}$

Iman Soetikno dalam bukunya memberikan definisi singkat tentang hak menguasai negara yaitu hak menguasi dari negara yang meliputi tanah dengan hakhak perorangan yang mana tanah tersebut dibiarkan tidak diurus/ditelantarkan. ${ }^{7}$

\footnotetext{
${ }^{2}$ Winahyu Erwiningsih, Hak Menguasai Negara Atas Tanah, (Yogyakarta: Total Media, 2009), hlm. 101

${ }^{3}$ Winahyu Erwiningsih, Pelaksanaan Pengaturan Hak Menguasai Negara atas Tanah Menurut UUD 1945 (Jurnal Hukum No. Edisi Khusus Vol. 16 Oktober 2009), hlm. 120

${ }^{4}$ Boedi Harsono, Hukum Agraria Indonesia (Jilid I),Edisi Revisi, (Jakarta: Djambatan, 1999), hlm. 169

${ }^{5}$ Boedi Harsono, Hukum Agraria Indonesia Edisi Revisi, (Jakarta: Djambatan, 2003), hlm. 47

${ }^{6}$ Rahmat Trijono, Hak Menguasai Negara di Bidang Pertanahan, (Jakarta: Badan Pembinaan Hukum Nasional, 2015), hlm. 3-4

${ }^{7}$ Iman Soetikno, Politik Agraria Nasional, cetakan ketiga, (Yogyakarta: Gadjah Mada Univcersity press, 1990), hlm. 53 
Berdasarkan pendapat tersebut maka dapat diketahui bahwa negara mempunyai hak dalam penguasaan tanah dengan catatan bahwa tanah tersebut merupakan tanah yang terlantar. Penguasaan tanah oleh negara dalam konteks di atas adalah penguasaan yang otoritasnya menimbulkan tanggungjawab, yaitu untuk kemakmuran rakyat. Di sisi lain, rakyat juga dapat memiliki hak atas tanah. Sedangkan hubungan negara dengan tanah melahirkan kewenangan dan tanggung jawab.

Darwis Anatami dalam tulisannya juga menyebutkan bahwa Negara ditugaskan untuk menguasai dan bukan untuk memiliki, oleh karenanya Negara berkewajiban untuk memberikan kepastian hukum tentang kepemilikan sebidang tanah, melalui permohonan hak dan pendaftaran tanah, agar dilakukan pengukuran sebagai dasar penerbitan sertipikat hak atas tanah sebagaimana ditegaskan dalam Pasal 19 (2), 23 (2), 32 (2) dan Pasal 38 (2) Undang-Undang Pokok Agraria (UUPA) No. 5 Tahun 1960. Guna menjamin kepastian hukum di bidang penguasaan dan pemilikan tanah faktor kepastian letak dan batas setiap bidang tanah tidak dapat diabaikan, banyak sengketa tanah yang timbul sebagai akibat letak dan batas bidang-bidang tanah tidak benar. ${ }^{8}$

Menyimak dari pada aspek kepemilikan tanah bagi setiap warga negara maka pembuktiannya berupa sertifikat tanah yang diterbitkan oleh lembaga yang berwenang. Sertifikat tanah mempunyai peranan penting dalam pembuktian apabila terjadi sengketa tanah dan disatu sisi juga apabila seorang warga negara yang tidak dapat membuktikan kepemilikan tanahnya maka tanah tersebut dipastikan kembali kepada negara untuk dikuasai berdasarkan ketentuan yang berlaku.

Persoalan tanah terlantar merupakan masalah pokok yang harus mendapat perhatian dan penanganan serius oleh negara. Bahkan kasus tanah terlantar yang ditangani melalui Peraturan Pemerintah Nomor 36 Tahun 1998 jo. PP No.11 Tahun 2010 tentang tentang Penertiban dan Pendayagunaan Tanah Terlantar belum bisa memberikan jaminan kepastian hukum karena setelah dinyatakan sebagai tanah terlantar namun hakhak perdatanya masih melekat.

Terkait data mengenai tanah terlantar sebagaimana disebutkan oleh Rahmadaini dalam penelitiannya menyebutkan bahwa di Aceh sampai saat ini jumlah total tanah-tanah yang terindikasi terlantar telah berjumlah 34,656.59 hektar, dan belum ada satupun yang ditetapkan sebagai tanah terlantar. ${ }^{9}$ Merujuk pada data tersebut maka dapat diidentifikasikan bahwa seyogyanya negara mempunyai wewenang untuk mengambil alih tanah yang diindikasikan terlantar tersebut dan dapat dipergunakan untuk kepentingan rakyat. Namun, belum adanya penetapan status tanah terlantar sebagaimana disebutkan oleh Rahmadaini justru menimbulkan polemik bagi masyarakat lainnya yang hendak mendayagunakan/mengurus/mengelola tanah tersebut.

Berdasarkan uraian yang telah dipaparkan di atas, maka dapat ditarik beberapa rumusan masalah yang layak dikaji dalam penelitian ini yaitu: 1) bagaimanakah bentuk wewenang negara dalam pendayagunaan tanah ditinjau menurut asas hak menguasai

\footnotetext{
${ }^{8}$ Darwis Anatami, Tanggung Jawab Siapa, Bila Terjadi Sertifikat Ganda Atas Sebidang Tanah, (Jurnal Hukum Samudra Keadilan, Vol. 12 No. 1 Tahun 2017), hlm. 1

${ }^{9}$ Rahmadaini, Ilyas Ismail, Eddy Purnama, Pelaksanaan Penertiban Tanah Terlantar Di Provinsi Aceh, (Jurnal Ilmu Hukum Pascasarjana Universitas Syiah Kuala, Volume 2, No. 2, 2013), hlm. 62
} 
negara?. 2) Bagaimanakah asas hak menguasai negara diterapkan di Aceh dalam hal pemanfaatan tanah oleh rakyat?

\section{Pembahasan}

\section{Bentuk Wewenang Negara Dalam Pendayagunaan Tanah Ditinjau Menurut Asas Hak Menguasai Negara}

Berbicara mengenai konteks negara tidak lepas dari hukum tata negara. Negara adalah daerah atau yang ada di permukaan bumi di mana terdapat pemerintahan yang mengatur ekonomi, politik, sosial, budaya, pertahanan keamanan, dan lain sebagainya. Di dalam suatu negara minimal terdapat unsur-unsur negara seperti rakyat, wilayah, pemerintah yang berdaulat serta pengakuan dari negara lain. ${ }^{10}$ Sebagai suatu organiasi tunggal, negara mempunyai tujuan yang diatur dalam konstitusi yang berlaku bagi seluruh rakyat dan dijadikan sebagai cita-cita bangsa.

Sebagaimana disebutkan bahwa unsur negara mencakup dari rakyat, wilayah dan pemerintahan yang mana ketiga unsur tersebut merupakan syarat mutlak berdiri sebuah organisasi disebut negara. Negara melalui otoritas kekuasaannya mempunyai hak dan kekuasaan dalam mengakomodir maupun merekayasa negara tersebut dengan tujuan kesejahteraan masyarakatnya. Rekayasa yang terbangun dalam sebuah sistem legalisasi tersebut didudukkan dalam posisi sebagai hukum tertinggi sehingga masyarakat patuh dan menjalankan setiap kebijakan negara tersebut. Hal itu disebut dengan konstitusi. ${ }^{11}$

Hal ini juga senada dengan cita hukum negara Republik Indonesia yang mengadopsi teori negara hukum, dimana tujuan negara hukum yaitu mensejahterakan rakyatnya. Tujuan negara hukum secara umum yaitu:

a. membatasi kekuasaan negara

b. menjamin kesejahteraan rakyat

c. melindungi HAM

d. menjamin kekuasaan presiden

e. memberi kebebasan individu. ${ }^{12}$

Melihat dari tujuan umum di atas, maka disimpulkan bahwa tujuan negara dengan kekuasaannnya adalah membatasi kekuasaan negara tersebut sendiri dan outputnya adalah mensejahterakan masyarakat dengan memberikan perlindungan dan pemenuhan hak asasi manusia bagi warga negaranya.

Pasal 33 ayat (3) UUDNRI Tahun 1945 merupakan landasan konstitusional bagi pembentukan politik dan Hukum Agraria nasional, yang berisi perintah kepada negara agar bumi, air dan kekayaan alam yang terkandung didalamnya yang diletakkan dalam penguasaan negara itu digunakan untuk mewujudkan sebesar-besarnya kemakmuran seluruh rakyat Indonesia.Tanah merupakan sarana vital bagi hidup dan kehidupan manusia. Oleh karena itu, tanah telah diatur di dalam Pasal 9 ayat (2) Undang-Undang Nomor 5 Tahun 1960 yang menyatakan bahwa tiap-tiap warga negara baik pria maupun

${ }^{10}$ B.F, Sihombing, Evolusi Kebijakan Pertanahan Dalam Hukum Tanah Idonesia, (Jakarta: Gunung Agung, 2005), hlm. 4

${ }^{11}$ Ibid.

${ }^{12}$ Moh. Mahfud MD, Hukum Dan Pilar-Pilar Demokrasi, (Yogyakarta: Gama Media, 1999), hlm. .132 
wanitamempunyai kesempatan yang sama untuk memperoleh sesuatu hak atas tanah serta untuk mendapatkan manfaat dan hasilnya bagi diri sendiri maupun keluarganya. Politik hukum berhubungan dengan kebijaksanaan untuk menentukan kaidah-kaidah hukum yang sesuai dengan ideology penguasa. ${ }^{13}$

Merujuk pada landasan di atas, maka negara mempunyai legalitas dalam menyelenggarakan kewenangan dibidang agraria. Wewenang negara dibidang agraria yaitu :

a. Mengatur dan menyelenggarakan peruntukkan, penggunaan, persediaan dan pemeliharaan bumi, air + ruang angkasa tersebut.

b. Menentukan dan mengatur hubungan-hubungan hukum antara orang-orang dengan bumi, air dan ruang angkasa.

c. Menentukan dan mengatur hubungan-hubungan hukum antara orang-orang dan perbuatan-perbuatan hukum yang mengenai bumi, air dan ruang angkasa. ${ }^{14}$

Tujuan wewenang itu diberikan untuk mencapai sebesar-besarnya kemakmuran rakyat dalam arti kebangsaan serta kesejahteraan dan kemerdekaan dalam masyarakat dan negara hukum Indonesia yang merdeka, adil dan makmur. ${ }^{15}$

HMN merupakan bagian dari hak bangsa yang beraspek publik. Aspek publik memposisikan negara sebagai organisasi kekuasaan tertinggi dalam Negara Kesatuan Republik Indonesia. Konsep ini berbeda dengan penguasaan atas tanah pada konsep feodal dimana raja sebagai pemilik (domain) tanah. HMN juga bukan konsep komunis, dimana tanah dimiliki secara bersama seluruh rakyat sehingga menututup sama sekali peluang adanya penguasaan individu.

Penguasaan tanah oleh negara merupakan bentuk tanggung jawab negara dalam mensejahterakan rakyat melalui pemanfaatan sumber-sumber agraria. Konsep tersebut dilakukan untuk mendistribusikan sumber-sumber agraria lebih adil sehingga terjadi pemerataan dalam pemanfaatannya. HMN lahir selain untuk kesejahteraan, sesungguhnya merupakan mekanisme untuk melindungi rakyat Indonesia dari penindasan-penindasan oleh individu maupun kelompok yang berkepentingan.

Perlu digarisbawahi ketentuan di atas bahwa legalisasi dan legitimasi kekuasaan negara atas pertanahan (bahagian dari bumi) tiada lain bertujuan untuk didayagunakan bagi sebesar-besarnya kemakmuran rakyat, dalam arti kebahagiaan, kesejahteraan, merdeka dan berdaulat di bidang pertanahan. Tentunya, tujuan tersebut sesuatu yang serius harus dicapai, bukan sekedar rangkaian kata-kata yang apik dan lugas tanpa ada realisasi in-konkrito.

Eksekutornya untuk mewujudkan cita-cita konstitusi tersebut adalah Pemerintah yang dalam hal ini dijalankan oleh Badan Pertanahan Nasional (BPN) dengan wilayah tugas di bidang pertanahan yakni permukaan tanah tidak meliputi kandungan dan kekayaan alamnya, dimana diantara kewenangan dan tugasnya adalah pengawasan dan pengendalian penguasaan terhadap tanah, dan melakukan pembatalan dan penghentian hubungan hukum antara orang, dan/atau badan hukum dengan tanah sesuai dengan ketentuan peraturan perundang-undangan yang berlaku.

\footnotetext{
${ }^{13}$ Bagas Riyady, Politik Hukum Agraria, http://bgazacha.blogspot.com/2012/05/politik-hukumagraria.html, diakses pada tanggal 13 Juni 2018

${ }^{14}$ Boedi Harsono, Hukum Agraria Indonesia ...., hlm. 553

${ }^{15}$ Ibid.
} 
Penertiban dan pendayagunaan tanah terlantar diharapkan menjadi resolusi dalam mencapai kemakmuran dan kesejahteraan rakyat di bidang pertanahan. Pemerintah telah menyusun aturannya yang sebelumnya tertuang di dalam Peraturan Pemerintah (PP) Nomor 36 tahun 1998, kemudian diganti dengan Peraturan Pemerintah (PP) Nomor 11 Tahun 2010 tentang Penertiban dan Pendayagunaan Tanah Terlantar. PP Nomor 11 tahun 2010 tidak mendefenisikan secara tegas arti Tanah Terlantar tetapi memberikan batasan Tanah Terlantar meliputi tanah yang sudah diberikan hak oleh Negara berupa Hak Milik, Hak Guna Usaha (HGU), Hak Guna Bangunan (HGB), Hak Pakai, dan Hak Pengelolaan, atau dasar penguasaan atas tanah yang tidak diusahakan, tidak dipergunakan, atau tidak dimanfaatkan sesuai dengan keadaannya atau sifat dan tujuan pemberian hak atau dasar penguasaannya. $^{16}$

Penertiban dan pendayagunaan sebagaimana dimaksud dalam regulasi di atas, merupakan langkah nyata negara dalam hal ini pemerintah melalui BPN untuk mencegah tindakan monopoli penguasaan tanah oleh pihak yang berkuasa. Sehingga tanah yang cakupan sangat luas dapat dibagikan kepada masyarakat lainnya untuk menunjang aspek kesejahteraan dan meningkatkan taraf kehidupannya.

Atas dasar fakta hukum tersebut, maka timbul pertanyaan (isu hukum) lainnya yang dapat dikaji dalam bagian permasalahan ini. Pertanyaan yang muncul adalah sebagai berikut: 1. Apakah pemerintah (pusat/daerah) mempunyai hak milik atas tanah? 2. Apakah Pemda boleh membagi tanah-tanah tersebut kepada pihak ketiga? 3. Apakah Pemda dapat menyewakan tanah-tanah tersebut? 4. Apakah masyarakat boleh mendapatkan hak milik atas tanah dari pemerintah?

Untuk menjawab pertanyaan di atas, maka dapat ditelusuri beberapa aspek yaitu tanah- tanah yang ada di daerah kabupaten atau kota tidak serta merta menjadi tanah Pemerintah daerah jika daerah ingin "memiliki" tanah -tanah tersebut, harus mengajukan permohonan hak pakai atau hak pengelolaan kepada Kepala Badan Pertanahan Nasional melalui Kantor Pertanahan Kabupaten/Kota setempat agar dikeluarkan sertipikat hak pakai atau sertipikat hak pengelolaan. Sehingga jelas dalam hal ini Pemda tidak punya hak milik atas tanah. Oleh karena itu, jika ada tanah hak pakai dan hak pengelolaan dijual, disewakan bahkah dijaminkan dibank, maka bupati/walikotanya dapat dipidana bahkan pidana korupsi jika ada dugaan menerima komisi dari tindakan tersebut dijerat dengan Undang-Undang No.31 tahun 1999 jo Undang- Undang No. 20 tahun 2001 tentang Pemberantasan Tindak Pidana Korupsi.

Apabila daerah tidak mempunyai hak atas tanah sebagaimana jawaban diatas, maka menarik ditelusuri terkait urusan pertanahan di daerah khusus, salah satunya Aceh. Berdasarkan Pasal 253 Undang-Undang Nomor 11 Tahun 2006 tentang Pemerintahan Aceh menyebutkan bahwa:

(1) Kantor Wilayah Badan Pertanahan Nasional Aceh dan Kantor Pertanahan kabupaten/kota menjadi perangkat Daerah Aceh dan perangkat daerah kabupaten/kota paling lambat awal tahun anggaran 2008.

16 Bambang Santoso, Pendayagunaan Tanah Terlantar Sebuah Resolusi, http://lawyersantoso.blogspot.com/2016/08/pendayagunaan-tanah-terlantar-sebuah.html, diakses pada tanggal 13 Juni 2018 
(2) Ketentuan lebih lanjut mengenai pelaksanaan hal sebagaimana dimaksud pada ayat (1) diatur dengan Peraturan Presiden.

Ketentuan Pasal 253 Undang-Undang Nomor 11 Tahun 2006 tentang Pemerintahan Aceh telah ditindak lanjuti dengan terbitnya Perpres nomor 23 tahun 2015 tentang Pengalihan BPN ke BPA, kemudian PP Kewenangan Nomor 3 tahun 2015, dan terakhir PP Pengelolaan Bersama bagi Hasil Migas nomor 23 tahun 2015. Statusnya BPN berubah menjadi BPA dan untuk tingkat kabupaten kota menjadi Kantor Pertanahan Aceh Kabupaten/Kota. Kebijakan ini merupakan bagian dari implementasi UUPA sekaligus bertujuan meningkatkan pelayanan. ${ }^{17}$

Dengan adanya dasar regulasi perubahan status BPN menjadi BPA serta menjadi bagian dari satuan perangkat daerah maka Aceh mempunyai hak dalam pengelolaan tanah secara penuh sepanjang masih sesuai dengan peraturan perundang-undangan yang berlaku. Setidaknya Aceh memiliki Sembilan urusan pertanahan sesuai PP No. 38 Tahun 2007. Selanjutnya dua urusan pertanahan lain diatur dalam Undang-Undang Pemerintahan Aceh, yaitu HGU (hak guna usaha dan HGB (hak guna bangunan), itu menjadi urusan pertanahan yang dilaksanakan Aceh.

Implikasi yang ingin dicapai dalam politik hukum pertanahan di Aceh dengan menjadikan BPN menjadi BPA ditujukan untuk mempercepat proses pelayanan kepada masyarakat dibidang pertanahan dan memberikan kepastian hukum dalam proses legalisasi tanah dalam bentuk hak atas tanah. Sehingga peran BPA dalam penanganan konlik pertanahan dapat dilakukan dengan cara melakukan konsolidasi kelembagaan BPA dalam memuat tugas dan fungsi BPA dalam qanun Aceh. ${ }^{18}$

Namun, pemberian wewenang dalam pengurusan bidang pertanahan kepada Aceh melalui UU No. 11 Tahun 2006 tentang Pemerintahan Aceh bukanlah sepenuhnya atau bersifat mutlak. Namun, masuk dibatasi dengan adanya regulasi nasional khususnya bidang agraria.

Ketentuan yang terdapat dalam Pasal 1 UU No.5 Tahun 1960 yang menyatakan bahwa tanah di daerah dan pulau bukan semata-mata menjadi hak rakyat asli daerah saja melainkan hak seluruh bangsa Indonesia ditegaskan bahwa subjek hukum pemegang hak atas tanah dapat berbentuk Bangsa Indonesia. UUPA telah mengatur strukur pendelegasian wewenang dari Negara pada pemerintah atau masyarakat untuk membentuk keseimbangan hak dan kewajiban perorangan, masyarakat, Negara.

Kewenangan Negara tersebut tertuang didalam pasal 2 UUPA yang selengkapnya berbunyi:

(1) Atas dasar ketentuan dalam pasal 33 ayat (3) Undang-undang Dasar dan hal-hal sebagai yang dimaksud dalam pasal 1, bumi, air dan ruang angkasa, termasuk kekayaan alam yang terkandung didalamnya itu pada tingkatan tertinggi dikuasai oleh Negara, sebagai organisasi kekuasaan seluruh rakyat.

\footnotetext{
17 "BPN Aceh belum Berubah Signifikan", http://aceh.tribunnews.com/2016/04/09/bpn-acehbelum-berubah-signifikan, diakses pada tanggal 13 Juni 2018

${ }^{18}$ Zaki Ulya, Eksistensi Badan Pertanahan Aceh sebagai Perangkat Daerah di Aceh dalam Aspek Kepastian Hukum Bidang Pertanahan, (Jurnal Konstitusi Volume 12, Nomor 3, September 2015), hlm. 584 
(2) Hak menguasai dari Negara termaksud dalam ayat (1) pasal ini memberi wewenang untuk :

a. mengatur dan menyelenggarakan peruntukan, penggunaan, persediaan dan pemeliharaan bumi, air dan ruang angkasa tersebut;

b. menentukan dan mengatur hubungan-hubungan hukum antara orang-orang dengan bumi, air dan ruang angkasa,

c. menentukan dan mengatur hubungan-hubungan hukum antara orang-orang dan perbuatan-perbuatan hukum yang mengenai bumi, air dan ruang angkasa.

Pasal 2 ayat (2) sub a UUPA tersebut memberi wewenang pada Negara untuk mengatur bahwa tanah-tanah didaerah tertentu diperuntukkan untuk keperluan tertentu, atau apakah orang boleh mendirikan pabrik diatas tanah miliknya atau tidak, bahkan untuk menentukan bahwa daerah tertentu akan digunakan sebagai hutan kota, dan sebagainya. Sub b -nya memberi wewenang kepada Negara untuk mengatur mengenai hak apa saja yang boleh dipunyai orang atas tanah, sifat hak tersebut, siapa yang bisa mempunyai tanah dengan hak tertentu, dan sebagainya. Sementara sub c memberi wewenang kepada Negara untuk mengatur apakah suatu hak boleh dialihkan pada pihak lain, apa syarat pengalihannya, apakah suatu hak boleh digunakan sebagai jaminan hutang, apakah orang boleh membiarkan saja hak atas tanahnya tanpa digunakan sama sekali, dan sebagainya.

Ketiga jenis kewenangan Negara tersebut sesungguhnya merupakan kewenangan pengaturan yang wajar dimiliki oleh Negara, meskipun dapat berakibat adanya pembatasan-pembatasan pada orang yang memegang hak tertentu atas tanah. Pembatasan-pembatasan yang ditentukan oleh Negara tersebut tentunya harus berdasarkan pada kepentingan rakyat Indonesia untuk sebesar-besar kemakmuran rakyat. Dengan demikian, hak atas tanah di Indonesia, termasuk hak milik bukan merupakan hak mutlak, yang memberi wewenang kepada pemegang haknya untuk melakukan tindakan apa saja semaunya sendiri atas tanah yang dihakinya tersebut.

Orientasi hak menguasai negara sebagaimana dimaksud adalah bersifat pelimpahan sebagian wewenang pemerintah pusat kepada Aceh melalui undang-undang khusus bidang pertanahan. Sungguhpun pelayanan masyarakat terkait hak atas tanah nantinya akan diatur dalam qanun aceh. Beberapa hal penting yang diatur dalam Perpres Nomor 23 Tahun 2015 tentang Pengalihan Kantor Wilayah Badan Pertanahan Nasional (Kanwil BPN) Aceh dan Kantor Pertanahan Kabupaten/Kota, yaitu: Pertama, pengalihan Kanwil BPN menjadi Badan Pertanahan Aceh (BPA) dan Badan Pertanahan Kabupaten Kota sebagai perangkat Daerah Aceh dan perangkat Kabupaten/Kota untuk melaksanakan pelayanan pertanahan di Aceh. Badan Pertanahan ini akan melaksanakan tugas dan fungsinya sesuai dengan ketentuan peraturan perundang-undangan. Bentuk dan susunan organisasi, tugas, serta fungsi BPA dan kabupaten/kota diatur dengan qanun Aceh dan qanun kabupaten/kota. Dengan demikian, qanun Aceh dan qanun kabupaten/kota menjadi penentu pelaksanaan tugas dan fungsi badan ini. ${ }^{19}$

19 Sulaiman Tripa, Pelayanan Pertanahan Aceh, http://aceh.tribunnews.com/2015/03/11/pelayanan-pertanahan-aceh, diakses pada tanggal 21 Juni 2018 


\section{Penerapan Asas Hak Menguasai Negara di Aceh Dalam Hal Pemanfaatan Tanah}

Peter Butt dalam bukunya Land Law menyebutkan bahwa Sebutan untuk "Tanah" (land) dapat mempunyai arti yang berbeda tergantung dari sudut pandang keilmuan untuk pengartikannya. Dalam konsep hukum tanah tidak sekedar permukaan bumi, namun mempunyai tiga dimensi yakni ruang angkasa, permukaan bumi dan dibawah tubuh bumi. $^{20}$

Kata "Tanah Negara" seperti hal sebutan tanah yang lain - misalnya tanah milik dan sebagainya - hal ini menunjukan suatu status hubungan hukum tertentu antara obyek dan subyeknya yang dalam konteks ini lebih kepada hubungan kepemilikanatau kepunyaan antara subyek dan obyek yang bersangkutan. Dalam pengertian tersebut maka jika kita menyebutkan tanah Negara artinya adalah tanah sebagai obyek dan Negara sebagai subyeknya dimana Negara sebagai subyek mempunyai hubungan hukum tertentu dengan obyeknya yakni tanah. adapun hubungan hukum itu dapat berupa hubungan kepemilikan kekuasaan atau kepunyaan. ${ }^{21}$

Didalam konsep hukum Sebutan menguasai atu dikuasai dengan dimiliki ataupun kepunyaan dalam konteks yuridis mempunyai arti/makna berbeda dan menimbulkan akibat hukum yang berbeda pula. Arti dikuasai tidak sama dengan pengertian dimiliki. ${ }^{22}$

Menurut Pasal 2 Ayat (2) Undang-Undang No. 5 Tahun 1960 menentukan rumusan Pembatasan kekuasaan Negara atas tanah, diantaranya:

a. Mengatur dan menyelenggarakan peruntukan, persediaan dan pemeliharaan

b. Menentukan hubungan hukum

c. Menentukan dan mengatur hubungan hukum antara orang dan perbuatan hukum. ${ }^{23}$

Dalam sejarah hukum pertanahan di Indonesia sejak zaman kesultanan, zaman kolonial, sampai zaman kemerdekaan, dalam prakteknya diperlakukan 3 (tiga) teori penguasaan tanah yakni teori eropa, teori adat dan teori hukum nasional. Ketiga teori ini silih berganti diterapkan di Indonesia sesuai dengan zamannya masing-masing. ${ }^{24}$

Teori eropa berorientasi pada pemberlakuan hak menguasai negara yang diterapkan pada zaman pemerintahan Hindia Belanda. Dasar pemikirannya adalah raja adalah penguasa mutlak atas tanah negara diberlakukan juga di Indonesia oleh penguasa bangsa eropa tersebut. Kebijakan pemberlakuan teori domein verklaring didasari atas alasan-alasan karena pemerintah Belanda menganggap raja-raja di Indonesia yang

${ }^{20}$ Peter Butt, Land Law, (Wales: Lawbook Company, 2001), hlm. 322

21 Boedi djatmiko, Tanah Negara Dan Wewenang Pemberian Haknya, http://sertifikattanah.blogspot.com/2008/08/tanah-negara-dan-wewenang-pemberian.html, diakses pada tanggal 21 Juni 2018

${ }^{22}$ Ibid.

${ }^{23}$ Ibid

${ }^{24}$ Syafruddin Kalo, Perbedaan Persepsi Mengenai Penguasaan Tanah dan Akibatnya Terhadap Masyarakat Petani di Sumatera Timur pada Masa Kolonial yang Berlanjut pada Masa Kemerdekaan, Orde Baru dan Reformasi, Program Studi Hukum Pidana Fakultas Hukum Universitas Sumatera Utara, t.t. hlm. 7 
mempunyai kekuasaan hak domein atas tanah maka dengan sendirinya hak domein itu juga diambil over oleh Belanda karena Belanda memegang kedaulatan di Indonesia. ${ }^{25}$

Selanjutnya terkait teori adat, Syafruddin Kalo menyebutkan dalam tulisannya bahwa Teori pemilikan tanah berdasarkan hukum adat adalah tanah merupakan milik komunal atau persekutuan hukum (beschikkingsrecht). Dalam hal ini setiap anggota persekutuan dapat mengerjakan tanah dengan jalan membuka tanah terlebih dahulu dan jika mereka mengerjakan tanah tersebut secara terus-menerus maka tanah tersebut dapat menjadi hak milik secara individual. ${ }^{26}$ Lebih lanjut Wignjodipoero dalam bukunya mengatakan bahwa "hak ulayat ini dalam bentuk dasarnya adalah suatu hak daripada persekutuan atas tanah yang didiami, sedangkan pelaksanaannya dilakukan atau oleh persekutuan itu sendiri atau oleh kepala persekutuan atas nama persekutuan". ${ }^{27}$

Berdasarkan teori ini maka hak-hak individual dan persekutuan terhadap tanah dan tetap diakui keberadannya yang mana hak itu diwariskan secara turun temurun terhadap anggota keturunan masyarakat persekutuan yang mengikatkan dirinya terhadap persekutuan adat tersebut.

Sementara itu, menurut teori nasional ditekankan pada pemberlakukan UU No. 5 Tahun 1960 sebagai dasar pemberian hak atas tanah secara nasional. Menurut Subekti, UUPA dimaksudkan untuk mengadakan Hukum Agraria Nasiona yang berdasarkan hukum adat tentang tanah, dengan kelahiran UUPA maka tercapailah suatu keseragaman menganai hukum tanah, sehingga tidak ada lagi hak atas tanah menurut hukum Barat disamping hak atas tanah menurut hukum adat. ${ }^{28}$

Apa yang menarik dalam kajian ini sebagaimana tema yang dibahas adalah adanya keterkaitan antara "Domein Verklaring" dengan Pemberian hak atas tanah yang dapat dikatakan menyimpang dalam proses pendaftaran tanah. Pernyataan pemberian hak atas tanah "yang menyimpang" yang dimaksudkan karena seringkali tidak sesuai dengan kenyataannya. Dalam pendaftaran tanah terdapat dua jenis cara dalam pembuktian hak, yaitu pemberian hak atas tanah dan konversi hak-hak lama. Dalam pemberian hak atas tanah yang menjadi objek pendaftaran tanah adalah tanah negara yang dimohonkan haknya. Dalam konversi terdapat tiga tingkatan pendaftaran, yang pertama adalah konversi hak-hak lama dengan alat bukti yang lengkap, yang dua adalah penegasan hak dengan alat bukti yang kurang lengkap dan yang ketiga adalah pengakuan hak untuk objek yang tidak memiliki alat bukati sama sekali.

Banyaknya muncul sengketa agraria bukanlah disebabkan kelemahan dari UUPA tersebut akan tetapi disebabkan penerapannya secara penuh sulit karena kentalnya arogansi sektoral berbagai pihak dan banyaknya tumpang tindih aturan dan ketentuan menyangkut pertanahan. Untuk itu turunan dari UUPA tersebut barangkali perlu ditinjau ulang disamping mental aparatur lembaga pertanahan Indonesia juga perlu diperbaiki.

Tanah yang dikuasai Negara bisa dimohonkan hak milik. Ketentuan dan tata caranya diatur dalam Peraturan Menteri Negara Agraria/Kepala Badan Pertanahan Nomor

${ }^{25}$ Ibid.

${ }^{26}$ Ibid., hlm. 8

${ }^{27}$ Soerojo Wignjodipoero, Pengantar dan Asas-Asas Hukum Adat, (Jakarta: PT. Gunung Agung, 1983), hlm. 199

${ }^{28}$ Subekti, Pokok-Pokok Hukum Perdata, (Jakarta: Intermasa, 1985), hlm. 93. 
9 Tahun 1999 tentang Tata Cara Pemberian dan Pembatalan Hak Atas Tanah Negara dan Hak Pengelolaan.

Pemberian dan pembatalan Hak Milik, Hak Guna Usaha, Hak Guna Bangunan, Hak Pakai dan Hak Pengelolaan dilakukan oleh Menteri Agraria dan Pertanahan/Kepala Badan Pertanahan Nasional ("Menteri"). ${ }^{29}$ Pemberian dan pembatalan hak ini, Menteri dapat melimpahkan kewenangannya kepada Kepala Kantor Wilayah, Kepala Kantor Pertanahan dan Pejabat yang ditunjuk..$^{30}$ Lebih lanjut mengenai pelimpahan kewenangan ini dapat dilihat dalam Peraturan Kepala Badan Pertanahan Nasional Republik Indonesia Nomor 2 Tahun 2013 tentang Pelimpahan Kewenangan Pemberian Hak Atas Tanah dan Kegiatan Pendaftaran Tanah.

Dalam hal keputusan pemberian hak milik kewenangannya telah dilimpahkan kepada Kepala Kantor Pertanahan Kabupaten/Kota, setelah mempertimbangkan pendapat Kepala Seksi Hak Atas Tanah atau pejabat yang ditunjuk atau Tim Penelitian Tanah atau Panitia Pemeriksa Tanah A, Kepala Kantor Pertanahan Kabupaten/Kota menerbitkan keputusan pemberian hak milik atas tanah negara yang dimohon atau keputusan penolakan yang disertai dengan alasan penolakannya.

Konstruksi hukum Sertifikat yang lahir dari pendaftaran tanah yang berasal dari tanah yang berstatus Negara mempunyai karakter yang bersifat "konstitutif". Sifat karekter ini timbul sebagai akibat adanya suatu keputusan atau penetapan dari badan / pejabat tata Usaha Negara dalam hal ini BPN yang menetapkan pemberian hak atas tanah kepada seseorang atau badan hukum yang mengajukan permohonan suatu hak atas tanah yang berstatus tanah Negara. Fungsi dari surat keputusan pemberian hak tersebut adalah sebagai tanda bukti kepemilikan bahwa seseorang atau badan hokum memperoleh hak atas suatu bidang tanah.

Menarik dikaji dengan adanya keberadaan BPA sebagai transformasi BPN di Aceh dalam pelayanan dibidang pertanahan. Dimana disebutkan dalam UU No. 11 Tahun 2006, BPA menjadi satuan kerja perangkat daerah memiliki kewenangan khusus yang diatur dalam qanun aceh dalam pengelolaan bidang pertanahan. Namun, wewenang dalam pengelolaan tanah tersebut tidaklah mutlak sebagaimana disebutkan pada pembahasan pertama, hanya sebagai pelimpahan wewenang dari pusat kepada daerah yang sejatinya juga masih mengikuti peraturan perundang-undangan yang berlaku. Salah satunya adalah mekanisme maupun tatacara pemberian hak atas tanah terhadap tanah negara juga tetap mengacu pada peraturan yang berlaku.

Terkait pengelolaan tanah terlantar di Aceh baik yang telah ditinggalkan pemiliknya maupun yang memang tidak ada pemiliknya (disebut juga dengan tanah mati), Aceh selaku daerah otonomi khusus melalui wewenang yang dimiliki BPA memiliki hak untuk mendayagunakan tanah tersebut untuk kepentingan rakyat. Selain berlaku hukum nasional dan hukum adat, di Aceh juga berlaku ketentuan hukum Islam. Sehingga tentunya pemerintah Aceh wajib dapat mengharmonisasikan ketiga sistem hukum tersebut dalam hal pertanahan.

${ }^{29}$ Pasal 3 ayat (1) Permen Argaria No. 9/1999

${ }^{30}$ Pasal 3 ayat (2) Permen Argaria No. 9/1999 
Dalam hukum Islam dikenal dengan istilah konsep Ihya al Mawat (menghidupkan tanah mati). Pengertian umumnya ihya al mawat adalah membuka lahan tanah mati dan belum pernah ditanami sehingga tanah tersebut dapat memberikan manfaat untuk tempat tinggal, bercocok tanam dan sebagainya. ${ }^{31}$

Mayoritas ulama berpendapat bahwa membuka lahan kosong menjadi sebab pemilikan tanah tanpa wajib diwajibkan izin dari pemerintah. Orang yang membuka lahan (tanah) baru otomatis menjadi miliknya tanpa perlu meminta izin lagi kepada pemerintah. Dan penguasa (pemerintah) berkewajiban memberikan haknya apabila terjadi persengketaan mengenai hal tersebut. ${ }^{32}$

Realisasi dalam pelaksanaannya di Aceh terkait pengelolaan tanah terlantar/tanah kosong/tanah mati yang wewenangnya dimiliki oleh BPA disatu sisi juga dimiliki oleh Baitul Mal. Qanun Aceh Nomor 10 tahun 2007 menetapkan bahwa Baitul Mal Aceh adalah sebuah lembaga daerah non struktural yang memiliki kewenangan untuk mengelola dan mengembangkan zakat, waqaf, harta agama dengan tujuan untuk kemaslahatan umat, serta menjadi wali/wali pengawas terhadap anak yatim piatu dan/atau pengelola harta warisan yang tidak memiliki wali berdasarkan syariat Islam. Baitul Mal dibagi ke dalam empat tingkat, yaitu tingkat Provinsi, Kabupaten/Kota, Kemukiman, dan Gampong. Hal ini disebutkan dalam Pasal 8 poin 5 Qanun Aceh Nomor 10 Tahun 2007 yaitu "Menjadi pengelola terhadap harta yang tidak diketahui pemilik atau ahli warisnya berdasarkan putusan Mahkamah Syariah". ${ }^{33}$

Maka prihal yang harus dipahami yaitu secara kelembagaan Baitul Mal maupun BPA melakukan koordinasi kelembagaan sebagai perwujudan dari negara (daerah) dalam mengelola tanah terlantar, dan tentunya melakukan harmonisasi hukum tanah di Aceh baik hukum nasional, hukum adat maupun hukum Islam. Hal ini guna menghindari sengketa pertanahan dan ketidak pastian hukum dalam pelayanan kepada masyarakat dibidang pertanahan.

\section{Penutup}

Negara merupakan suatu organisasi tunggal yang memiliki kewenangan dalam menguasai dan mendayagunakan tanah. Pelaksanaan kewenangan hak menguasai negara diatur dalam UU No. 5 Tahun 1960. Pernyataan "dipergunakan" megandung suatu perintah kepada suatu negara untk mempergunakan bagi sebesar-besarnya kemakmuran rakyat, perintah sebagaimana diamanatkan dalam UUD NRI Tahun 1945 yang berisi keadaan berbuat, berkehendak agar sesuai dengan tujuannya. Kurangnya pemahaman atas makna, subtansi atas maksud dan tujuan menguasai negara atas tanah tidak mustahil mudah untuk disalagunakan dan disalah tafsirkan bahwa negara adalah organ kekuasaan yang mandiri terlepas dari maksud yang terlepas dan tujaun dibentuknya. Pemanfaatan tanah dilakukan negara melalui pemerintah dengan melimpahkan kewenangannya secara horizontal kepada daerah.

31 "Ihya Al- Mawat - Hukum Perdata Islam”, http://farchanbinadnan.blogspot.com/2009/12/ihyaal-mawat-hukum-perdata-islam.html, diakses pada tanggal 22 Juni 2018

32 Zaki Ulya, Espaktasi Pengelolaan Tanah Terlantar Oleh Baitul Mal Dalam Peningkatan Kesejahteraan Masyarakat, (Jurnal Hukum dan Pembangunan, Vol 46, No 4 2016), hlm. 504

33 "Profil", http://baitulmal.acehprov.go.id/?page_id=1549, diakses pada tanggal 22 Juni 2018 
Secara kelembagaan di Aceh menurut UU No. 11 Tahun 2006 memiliki dua lembaga yang berwenang dalam mengelola tanah yaitu BPN yang telah ditransformasikan menjadi BPA sebagai perangkat daerah dan Baitul Mal. Hal ini dapat dipahami di Aceh memiliki tiga sistem yang berlaku, yaitu hukum nasional, hukum adat dan hukum Islam. Guna mengharmonisasikan ketiga sistem hukum tersebut tentu pula perlu dilakukan harmonisasi kelembagaan antara BPA dan Baitul Mal dalam hal wewenang menguasai, mengelola dan mendayagunakan tanah terlantar di Aceh.

\section{Daftar Pustaka}

\section{Buku}

Boedi Harsono, Hukum Agraria Indonesia (Jilid I),Edisi Revisi, Djambatan, Jakarta, 1999 Hukum Agraria Indonesia Edisi Revisi, Djambatan, Jakarta, 2003

Darwis Anatami, Tanggung Jawab Siapa, Bila Terjadi Sertifikat Ganda Atas Sebidang Tanah, Jurnal Hukum Samudra Keadilan, Vol. 12 No. 1 Tahun 2017

Effendi Perangin, 401 Pertanyaan dan Jawaban tentang Hukum Agraria, Cet. I, Rajawali, Jakarta, 1986

Iman Soetikno, Politik Agraria Nasional, cetakan ketiga, Gadjah Mada Univcersity press, Yogyakarta, 1990

Mahfud MD Moh., Hukum Dan Pilar-Pilar Demokrasi, Gama Media, Yogyakarta, 1999

Peter Butt, Land Law, Lawbook Company, Wales, 2001

Rahmadaini, Ilyas Ismail, Eddy Purnama, Pelaksanaan Penertiban Tanah Terlantar Di Provinsi Aceh, Jurnal Ilmu Hukum Pascasarjana Universitas Syiah Kuala, Vol. 2, No. 2, 2013

Rahmat Trijono, Hak Menguasai Negara di Bidang Pertanahan, Badan Pembinaan Hukum Nasional, Jakarta, 2015

Sihombing B.F,. Evolusi Kebijakan Pertanahan Dalam Hukum Tanah Idonesia, Gunung agung, Jakarta, 2005

Soerojo Wignjodipoero, Pengantar dan Asas-Asas Hukum Adat, PT. Gunung Agung, Jakarta, 1983

Subekti, Pokok-Pokok Hukum Perdata, Intermasa, Jakarta, 1985

Syafruddin Kalo, Perbedaan Persepsi Mengenai Penguasaan Tanah dan Akibatnya Terhadap Masyarakat Petani di Sumatera Timur pada Masa Kolonial yang Berlanjut pada Masa Kemerdekaan, Orde Baru dan Reformasi, Program Studi Hukum Pidana Fakultas Hukum Universitas Sumatera Utara, t.t.

Winahyu Erwiningsih, Pelaksanaan Pengaturan Hak Menguasai Negara atas Tanah Menurut UUD 1945, Jurnal Hukum No. Edisi Khusus Vol. 16 Oktober 2009

Winahyu Erwiningsih,Hak menguasai negara atas tanah,Total media,yogyakarta,2009

Zaki Ulya, Eksistensi Badan Pertanahan Aceh sebagai Perangkat Daerah di Aceh dalam Aspek Kepastian Hukum Bidang Pertanahan, Jurnal Konstitusi Vol. 12, No. 3, September 2015 


\section{Peraturan Perundang-Undangan}

Undang-Undang Dasar Negara Republik Indonesia Tahun 1945

Undang-Undang Nomor 5 Tahun 1960 tentang Pokok-Pokok Agraria

Undang-Undang Nomor 11 Tahun 2006 tentang Pemerintahan Aceh

Peaturan Presiden Nomor 23 Tahun 2015 tentang Pengalihan Kantor Wilayah Badan Pertanahan Nasional (Kanwil BPN) Aceh dan Kantor Pertanahan Kabupaten/Kota

Qanun Aceh Nomor 10 Tahun 2007 tentang Baitul Mal

Peraturan Menteri Negara Agraria Nomor 9 Tahun 1999 Tentang Tata Cara Pemberian Dan Pembatalan Hak Atas Tanah Negara Dan Hak Pengelolaan

\section{Internet}

Bagas Riyady, Politik Hukum Agraria, http://bgazacha.blogspot.com/2012/05/politikhukum-agraria.html, diakses pada tanggal 13 Juni 2018

"Profil", http://baitulmal.acehprov.go.id/?page_id=1549, diakses pada tanggal 22 Juni 2018

"Ihya Al- Mawat - Hukum Perdata Islam", http://farchanbinadnan.blogspot.com/2009/12/ihya-al-mawat-hukum-perdataislam.html, diakses pada tanggal 22 Juni 2018

Boedi djatmiko, Tanah Negara Dan Wewenang Pemberian Haknya, http://sertifikattanah.blogspot.com/2008/08/tanah-negara-dan-wewenangpemberian.html, diakses pada tanggal 21 Juni 2018

Sulaiman Tripa, Pelayanan Pertanahan Aceh, http://aceh.tribunnews.com/2015/03/11/pelayanan-pertanahan-aceh, diakses pada tanggal 21 Juni 2018

Bambang Santoso, Pendayagunaan Tanah Terlantar Sebuah Resolusi, http://lawyersantoso.blogspot.com/2016/08/pendayagunaan-tanah-terlantarsebuah.html, diakses pada tanggal 13 Juni 2018

“BPN Aceh belum Berubah Signifikan”, http://aceh.tribunnews.com/2016/04/09/bpnaceh-belum-berubah-signifikan, diakses pada tanggal 13 Juni 2018 